\title{
The European Composite Administration Facing the Challenges of Migration
}

\begin{abstract}
In classical theoretical reflections on international reality, one of the leading paradigms is the belief that the Westphalian order based on sovereign states has evolved into a diverse network of interdependent actors. From a legal perspective, a network such as this has the character of multi-level normative linkages. Legislation with varying degrees of impact in terms of its binding force is enacted within a number of parallel consultative bodies. Within the EU this network takes on a concretised, institutionalnormative dimension, the so-called European Composite Administration which is evident in specific areas such as cyber security, asylum and migration policies, energy, and financial market regulation.

In the European Union, decentralised agencies play a leading role in a such compound bureaucracy. They are one of the main instruments in the European system for harmonising regulation and practices in specific areas of EU activity. In a crisis situation there is an increasing tendency to modify their powers. Within the European Composite Administration, bodies such as EASO, the agency responsible for migration and asylum policies, play a key coordinating role between the Member States.

The crisis legitimises institutional changes, by expanding the catalogue of regulatory agencies' competencies. While practitioners, especially in individual offices in the Member States, may find such processes acceptable in relation to the ideal of efficient and effective administration, these phenomena may be regarded as worrying from the point of view of control over a growing complex integrated administrative apparatus.
\end{abstract}

Keywords: European Composite Administration, Migration Policy, Asylum Policy, Harmonisation, Regulation

* Natalia Kohtamäki - Cardinal Stefan Wyszyński University in Warsaw, e-mail: n.kohtamaki@uksw.edu.pl, ORCID: 0000-0002-3094-4614. 


\section{Introduction}

Theoretical concepts are an important instrument to explain the phenomena and processes that one can observe in a dynamically changing world. Many parallel theoretical concepts have been developed to describe the institutional changes which have been taking place within the structures of the European Union. Among those worth mentioning is for example, the concept developed by Nordic centres, especially Norwegian researchers, which in the literature on political science and administration functions as the "European Executive Order". According to Jarle Trondal, the "father" of this concept: "the European Executive Order' transforms an inherent Westphalian order to the extent that an intergovernmental dynamic is supplemented by different mixes of supranational, departmental, and/or epistemic dynamics. (...) The nucleus of an emergent European Executive Order is the Commission, supplemented by a mushrooming parallel administration consisting of EU-level agencies and webs of EU-committees". ${ }^{1}$

Alternative terms that indicate the executive component of the system of EU institutions are "European Composite Administration" and "European Administrative Space". The first term has its origins in German doctrine and is often used synonymously with the term "European Integrated Administration”. Both terms will also be used interchangeably in this text.

The concept of the European Composite/Integrated Administration is the most precise when it comes to analysing complex administrativelegal relations in the European system. It distinguishes between several parallel and intertwining levels of administrative law: (1) administrative law to be implemented by the EU-administration, (2) administrative law originating from EU sources (regulations and directives) implemented by national administration in the EU Member States and (3) so-called "Europeanised" national administrative law, i.e. national legal acts under European influence. ${ }^{2}$

The alternative concept of European administrative space refers to an enigmatic "space" in which laws are harmonised. It is close to the concept of the European Regulatory Union, in which emphasis is placed on the

${ }^{1}$ J. Trondal, An Emergent European Executive Order, Oxford 2010, pp. 2 ff. See also D. Curtin, M. Egeberg, Tradition and Innovation: Europe's Accumulated Executive Order, in: Towards a New Executive Order in Europe, eds. D. Curtin, M. Egeberg, LondonNew York 2009, pp. 4 ff.

2 See M. Ruffert, European Administrative Law. Annual Report: Germany, "Ius Publicum Network Review", October 2011, p. 3. 
regulatory activity of various $\mathrm{EU}$ institutions and the impact of this activity on national legal orders. ${ }^{3}$

\section{The Concept of the European Composite Administration}

In German there is the term "Verwaltungsverbund", which reflects German thinking on the application of law in the administrative structure of the federal state. The term was later transformed into "europäischer Verwaltungsverbund" - in English, "European Composite/ Integrated Administration", to describe the phenomenon of integrating European administrative structures and norms. The term is intended to conceptualise the intensive interconnection of various administrative levels which goes far beyond mere cooperation, combines cooperative and hierarchical elements, and implies an integration that is functionally close to a unified administration. ${ }^{4}$ Different bodies at federal and central levels work together to carry out administrative tasks. They form a national legal order (Germ. Rechtsordnung) which, as Eberhard Schmidt-Aßmann, one of the leading contemporary European theorists of administrative law puts it, is by no means a monolith. ${ }^{5}$

In the case of a federal state such as the Federal Republic of Germany, a complexity of legal orders, or even a multiplicity of complementary legal orders, can be observed. The main dividing line is between the federation (Germ. Bund) and the federated states (Germ. Länder). The constitutionally guaranteed division of tasks between the federation and the states does not, however, mean that the different levels of government are separated from one another. It is, in fact, to the contrary; it determines their close cooperation. Hence, this special relationship in the multi-level German administration is referred to as cooperative federalism. ${ }^{6}{ }^{\text {The search for }}$ consensus is considered by German administrative lawyers as one of the

${ }^{3}$ Eg. E. Heidbreder, Structuring the European Administrative Space: Policy Instruments of Multi-level Administration, "Journal of European Public Policy", no. 5/2011, pp. 709 ff.; H.C.H. Hofmann, Mapping the European Administrative Space, "West European Politics", no. 4/2008, pp. 662 ff.; J. Olsen, Towards an European Administrative Space?, "Journal of European Public Policy", no. 4/2003, pp. 506 ff.; H.C.H. Hofmann, A European Regulatory Union? The Role of Agencies and Standards, in: Research Handbook on the Law of the EU's Internal Market, eds. P. Koutrakos, J. Snell, Cheltenham 2017, pp. $462 \mathrm{ff}$.

4 The definition by W. Weiß, Der Europäische Verwaltungsverbund. Grundfragen, Kennzeichen, Herausforderungen, Berlin 2010, pp. $17 \mathrm{f}$.

${ }^{5}$ See E. Schmidt-Aßmann, Einheit und Kohärenz der europäischen Mehrebenenrechtsordnung, "Europäische Grundrechte. Zeitschrift", no. 5-9/2016, pp. 87 ff.

6 K.M. Bezubik, Bundestag a parlamenty krajowe, "Białostockie Studia Prawnicze", no. 4/2019, p. 80. 
basic elements of the functioning of the German administrative system. In the case of Germany, we are dealing with the concept of functional, or in other words executive, federalism, in which competences are divided between the federation and its constituent parts in a simplified manner in the following way: the legislative power rests predominantly at the federal level and the most of administrative functions rest with the federated states. $^{7}$

Theoretical considerations about the administrative structure of the EU system have strong references especially in European doctrine to the German system, which has become an inspiration in conceptual attempts to understand the special, dynamically developing European administrative system. European "joint federalism" is classified as a special "middle ground" or "as a third category between confederation and federation". ${ }^{8}$ For several decades, legal scholars analysing the development of European law have been observing the combination of two seemingly opposing principles in EU structures - the principle of cooperation and the principle of hierarchy. The hierarchical nature of the national legal order is not possible even in such deeply integrated structures as the EU. This is due to the peculiarities of an international organisation, which is a reflection of the will of the Member States co-shaping it. The answer to hierarchy in international structures is polyarchy. It assumes a multiplicity of parallel, horizontal relationships of diverse actors. ${ }^{9}$

In this context in political science scholarship, the term of "governance without government" was developed. ${ }^{10}$ Legal scholars recognise rather the multiplicity of institutional links which have a direct impact on shaping common legal solutions accepted by all participating states. Polyarchic legal order is derived from diverse pluralistic decisionmaking processes involving technocratic elites empowered to decide on the basis of their expert knowledge. ${ }^{11}$ Such elites do not have any

\footnotetext{
7 Cf. U. Karpen, Competition versus Cooperation: German Federalism in Need of Constitutional Amendments, "Amicis Curiae", no. 70/2007, p. 13.

8 See S. Hoffmann, Obstinate or Obsolete? The Fate of the Nation-State and the Case of Western Europe, "Deadalus", no. 3/1966, p. 910; A. Glencross, What Makes the EU Viable? European Integration in the Light of the Antebellum US Experience, Basingstoke 2009, pp. $9 \mathrm{f}$.

9 E.g. A. Glencross, E Pluribus Europa? Assessing the Viability of the European Union by Analogy with the Early American Republic, "International Social Science Review", no. 1-2/2009, p. 29; F. Scharpf, The Foint-Decision Trap: Lessons from German Federalism and European Federation, "Public Administration", no. 3/1988, p. 240.

${ }_{10}$ Cf. O. Young, Governance in World Affairs, Ithaca-London 1999, pp. 1-23.

11 More: A. Peters, S. Peter, International Organizations: Between Technocracy and Democracy, in: The Oxford Handbook of the History of International Law, eds. B. Fass-
} 
links with voters nor, more broadly, with public opinion. The decisionmaking processes in these bodies and the accompanying creation of regulations, most often of a soft-law nature, take place outside classic democratic legitimacy. ${ }^{12}$

The multiplicity of institutions at the international level involved in the preparing and issuing of rules subsequently implemented by national administrations is steadily growing. These phenomena, which have been observed for more than twenty years, together with the intensive development of international cooperation and new challenges such as various crises, e.g. the migration crisis or the pandemic crisis, are becoming a permanent component of the development of national and international administrative law. The question that arises with this development of public administration is, Which level of governance shall do how much implementing of transnational regulations in specific areas of the market? ${ }^{13}$

In the case of the European Union, lurching from one crisis to another can be seen as its speciality. ${ }^{14}$ As a result, the EU must take actions against crises and creates complex networks of diverse bodies involved in, for example, migration policy-making. These can be seen as "compound bureaucracies" or "bureaucratic bargaining systems", ${ }^{15}$ i.e. "compound systems of public administration that blend departmental, epistemic and supranational decision-making dynamics". ${ }^{16}$ From the point of view of its citizens, their activities are opaque. Such "compound

bender, A. Peters, Oxford 2012, pp. 170 ff.; J. Trondal et al., Unpacking International Organisations. The Dynamics of Compound Bureaucracies, Manchester-New York 2010, pp. $111 \mathrm{ff}$.

12 See D. Lopes, Polyarchies, Competitive Oligarchies, or Inclusive Hegemonies? 23 Global Intergovernmental Organizations Compared, "GIGA Working Papers", no. $265 / 2015$, p. 6 .

13 "If administrative law is, among other things, the set of rules for the creation and implementation of regulation, then as we anticipate the growth of transnational regulation with its endemic problems - problems created by the question of which level of governance does how much of what - we might anticipate the growth of transnational administrative law". Cf. M. Shapiro, "Deliberative", "Independent" Technocracy v. Democratic Politics: Will the Globe Echo the EU?, "Law and Contemporary Problems", no. 3-4/2015, pp. 342 ff.

${ }_{14}$ One may wonder what really constitutes a crisis and whether every difficulty that such a large and complex organisation as the European Union has to overcome should be called a crisis. See A. Glencross, E Pluribus Europa?, op.cit., pp. $26 \mathrm{ff}$.

15 R. Dahrendorf, Class and Class Conflict in Industrial Society, Stanford 1959, pp. 64-67; Y. Hegele, Explaining Bureaucratic Power in Intergovernmental Relations, "Public Administration", no. 4/2019, pp. 755 ff.

${ }_{16}$ J. Trondal et al., op.cit., p. 3. 
bureaucracies" are networks of "insider" rulers who, on the basis of their expertise, support decision-making bodies such as the European Commission in drafting specific normative solutions, i.e. regulations and directives. ${ }^{17}$

\section{The Efficiency of European Integrated Administration}

In the theory of administrative law in recent years, the fashionable term of the "externalisation" of public administration tasks to substantively prepared entities has been adopted. ${ }^{18}$ The externalisation of administrative tasks is there to increase the efficiency and effectiveness of the public administration which has to respond to market needs and fulfil more and more specialised tasks. ${ }^{19}$ In this case, the urgent need to "modernise" public administration activities is indicated. Decision makers are looking for innovations in public management. Welfare states such as Scandinavian countries are becoming a model in which, as part of the implementation of the New Public Management concept, ${ }^{20}$ public services are being modified using economic and sociological research. ${ }^{21}$ Both at the level of national administrative systems and within international administrative networks, as in the case of the European Union, special research centres create economic reports indicating the so-called economies of scale and the necessity to transform existing structures towards their unification and the transfer of tasks to entities specifically prepared for creating consensual solutions. ${ }^{22}$ These may be expert bodies, as is the case, for

17 See N. Kohtamäki, Theorising the Legitimacy of EU Regulatory Agencies, Berlin 2019, pp. $201 \mathrm{ff}$.

18 More: B. Cuadrado-Ballesteros, The Impact of Functional Decentralization and Externalization on Local Government Transparency, "Government Information Quarterly", no. 2/2014, pp. 265 ff.; D. Argento et al., The Externalization of Local Public Delivery: Experience in Italy and Sweden, "International Journal of Public Policy", no. 1/2010, pp. $41 \mathrm{ff}$.

19 As Martin Shapiro commented on this evolution more than 15 years ago: "One cannot regulate what one does not understand". See M. Shapiro, op.cit., p. 343.

${ }^{20}$ It is a managerial rather than an administrative approach to provision of public services. More: T. Tiefenbach, New Public Management in Public Sector Organizations: The Dark Side of Managerialistic Enlightenment, "Public Administration", no. 4/2009, pp. $893 \mathrm{ff}$.

${ }^{21}$ E.g. A. Moisio et al., Public Services at the Local Level. The Finnish Way, "Government Institute for Economic Research. Policy Reports", no. 2/2010, pp. $38 \mathrm{ff}$.

22 See J. Malan et al., The Cost of Non-Agencies with Relevance to the Internal Market, „Policy Department D. Budgetary Affairs”, no. PE 572.702/2016; D. Parker, C. Kirkpatrick, Measuring Regulatory Performance, "OECD Expert Paper", no. 3/2012. 
example, with the European Union's decentralised agencies, which build the administrative apparatus supporting the European Commission with expertise in the preparation of regulations. They may also be private entities to which public administration bodies outsource the performance of specific tasks. ${ }^{23}$

Compound bureaucracies involving multiple actors at different levels are expected to respond more efficiently, quickly and effectively to the challenges of dynamically integrating free market economies. ${ }^{24}$ This corresponds to Max Weber's vision of modern administration, according to which bureaucracy is the rational form of rule, the main characteristics of which are objectivity, impersonality, and predictability. According to Max Weber, the decisive reason for the primacy of the bureaucratic organisation has always been its purely technical superiority over any other form of organisation. ${ }^{25}$

For at least three decades, a progressive trend towards the integration of public administration in integrating Europe can be observed. In the initial phases of European integration (from the 1950s to the 1970s), the European Communities functioned primarily as a platform for economic cooperation. The mechanisms for harmonising the normative framework were coordinative in nature. Common standards were sought to facilitate economic cooperation. The principles of subsidiarity and proportionality (Article 5(3) TEU) played a key role in the process of harmonising regulations. In simple terms, these principles define EU action in areas which do not fall within its exclusive competence. They have played a key role in the formation of the Union as a sui generis international organisation, in which one can observe specific power-sharing between various actors at the supranational, national, and regional levels. ${ }^{26}$ This special "in between" order has been changing. Since the 1980s, the deepening of cooperation in various areas of the market and the extension of integration to dimensions other than the economic, including above

${ }^{23}$ On the role of private and public institutions contracted by national and international administrations to perform specific tasks, see U. Widmaier, R. Freriks, Die Modernisierung öffentlicher Verwältung. Zum Verhältnis öffentlicher und privater Güterproduktion, "Diskussionspapiere aus der Fakultät für Sozialwissenschaft der Universität Bochum", no. 8/1996.

${ }^{24}$ Cf. S.P. Osborne, K. Brown, Managing Change and Innovation in Public Service Organizations, London 2005, pp. 24 ff.

${ }_{25}$ M. Weber, Wirtschaft und Gesellschaft, Tübingen 1972, p. 561.

26 More: W. Phelan, What is Sui Generis about the European Union? Costly International Cooperation in a Self-Contained Regime, "International Studies Review", no. $3 / 2012$, p. 367 . 
all the political dimension, have resulted in a dynamic evolution of the existing institutional and normative mechanisms. ${ }^{27}$

The last thirty years have seen a transformation of the governance mechanisms within the EU system. These processes taking place at various levels of making and enforcing EU law are described as "going from government to governance" or, as said above, "governing without government". Government implies a commitment to traditional models of governing within the state and the activities of its organs. Governance, on the other hand, is the area of co-determination of the many public and private actors involved, who actively participate in the processes referred to as "standard-setting" (so-called post-legislative guidance including soft law instruments). ${ }^{28}$

Undoubtedly, such hybridisation of law, i.e. the transformation of administrative law, is connected with the search for innovative and efficient solutions in public administration. In the case of the European Union, this means dealing with complex implementation tasks in an increasing number of integrated policy fields. This is the so-called EU executive federalism or European executive order. Public administration in the Member States and in the EU should be seen as co-dependent organisms. This administrative convergence, which is explicitly regulated in Article 197 TFEU, means that "The Union may support the efforts of Member States to improve their administrative capacity to implement Union law". ${ }^{29}$

\section{The Common European Asylum System}

Traditionally, EU law is mainly implemented by national authorities (Article 291 (1) TFEU). By contrast, individual policies are shaped at the EU level. As pointed above, the EU can introduce minimum rules for functions and procedures on the basis of substantive EU law, for example as regards the internal market, but also migration policy. However, its competences to regulate internal functions of administrative bodies in

27 Cf. T. Risse-Kappen, Exploring the Nature of the Beast: International Relations Theory and Comparative Policy Analysis Meet the European Union, "Journal of Common Market Studies", no. 1/1996, pp. 53 ff.

28 See R. Grzeszczak, The Concept and Practice of Good Governance in the European Union, "International Journal of Social, Behavioral, Educational, Economic Law and Political Sciences", no. 2/2015, p. 450.

29 Cf. S. Cassese, Der Einfluß des gemeinschaftsrechtlichen Verwaltungsrechts auf die nationalen Verwaltungssysteme, "Der Staat", no. 33/1994, pp. 25 ff.; R. Grzeszczak, Towards a European Administrative Space, "University of Warsaw Journal of Comparative Law", no. 1/2014, p. 14. 
the EU Member States are limited. Specific regulations are therefore implemented, often with great flexibility by the administrations of the Member States. This distribution of competences follows directly from Article 5(2) TEU, which introduces the so-called principle of conferral. This principle means that the EU may only act in areas in which its Member States have transferred competence to it. According to Article 6(g) TFEU: "The Union shall have competence to carry out actions to support, coordinate or supplement the actions of the Member States. The areas of such action shall, at European level, be inter alia administrative cooperation". The Lisbon Treaty not only legitimised the very idea of administrative cooperation, but in Article 298(1) TFEU it also legitimised the model of the European administration which should support the EU institutions, bodies, offices, and agencies in carrying out their missions. ${ }^{30}$

One of the main motives for developing such a model of European composite administration is its ability to resolve common European problems which are beyond the reach of individual administrative bodies, be they at the EU or national levels. ${ }^{31}$ In the case of instability, regardless of the sector of the economy in which such a disturbance occurs, there are regular calls in various international regimes for the improvement of joint crisis management. This is the time when demands for common solutions unifying the different normative orders intensify. In the case of the European Union, such processes take the form of a progressive institutionalisation of existing cooperation. ${ }^{32}$ They can also take form of qualitative "agentification", i.e. they may involve delegating more and more specific powers to EU decentralised agencies. ${ }^{33}$

In the case of the migration crisis, cooperation on asylum policy has been intensified. ${ }^{34}$ The functioning of yet another "common administrative space" system has been transformed in addition to those already existing in other areas such as energy or telecommunications. Mechanisms for the unification of national asylum procedures were developed under the Common European Asylum System (CEAS), which was established in

30 See J. Reichel, Communicating with the European Composite Administration, "German Law Journal”, no. 5/2014, pp. 885 f.; E. Nieto-Garrido, Possibile Developments of Article 298 TFEU: Towards an Open, Efficient and Independent European Administration, "European Public Law", no. 2/2012, pp. 374 ff.

31 More: J. Reichel, op.cit., p. 889.

32 More: M. Ruffert, C. Walter, Institutionalised International Law, Baden-Baden 2015, pp. $20 \mathrm{ff}$.

${ }_{33}$ M. Chamon, EU Agencies. Legal and Political Limits to the Transformation of the EU Administration, Oxford 2016, p. 46.

34 On changing EU Agenda concerning these issues see Making the CEAS Work. Starting Today, "ECRE's Policy Note”, no. 22/2019, pp. 2 ff. 
1999. ${ }^{35}$ Emerging modifications resulted from the challenges faced by Member States with the migrant crisis unfolding since 2015. The main problems include a record number of migrants, asylum-seekers, and refugees, difficulties in the management of these flows, bad organisation of refugee camps as well as a lack of solidarity and agreement about the European relocation scheme. ${ }^{36}$

Despite the fact that migration policy has been shaped in the integrated structures of the EU for more than twenty years, both the EU institutions and the Member States themselves were not prepared for such a dynamic development of the crisis situation. According to Natascha Zaun: “(...)EU asylum policy was one of the most dynamic areas of European integration in the 2000s, with a constant production of new regulatory instruments. (...) (T)he EU has harmonised asylum systems in its Member States and regulated the distribution of asylum-seekers only on paper. In practice, EU integration on a high level of protection has not succeeded" ${ }^{37}$ Migration, or the so-called refugee crisis, was therefore a management crisis, which showed that diverse, deliberative networks and soft regulations do not work during a crisis.

Cooperation in the area of migration and asylum regulation is intergovernmental (the form of bilateral or multilateral agreements between the Member States) and takes place primarily on the basis of the goodwill of the participating countries in adopting certain recommendations. It was, therefore, up to the Member States to standardise migration issues. Gradually, however, the EU's participation in shaping migration policy has increased. A significant turning point was the signing of the Schengen Treaty and the Treaty of Amsterdam, which transferred important powers in the area of border control, bilateral agreements and visa and asylum systems to the EU level. ${ }^{38}$

It was assumed from the beginning of the CEAS that the Member States have a shared responsibility to welcome asylum seekers in the

${ }^{35}$ See Establishing the Second-Phase of a Common European Asylum System (CEAS): An Assessment of the Current State-of-Play, February 2013, https://www.ies.be/lectureseries/establishing-second-phase-common-european-asylum-system-ceas-assessment-current-state (access 20.05.2021).

${ }^{36}$ Asylum flows are not constant. They have, for example, varied from over $1.8 \mathrm{mil}-$ lion in 2015 to around 142,000 in 2019, a decrease of $92 \%$. See https://ec.europa.eu/ home-affairs/what-we-do/policies/asylum_en (access 20.05.2021).

${ }^{38}$ E.g. J. Estevens, Migration Crisis in the EU: Developing a Framework for Analysis of National Security and Defence Strategies, “Comparative Migration Studies”, no. 6/2018, pp. 3, 15. 
sense that, "no matter where an applicant applies the outcome should be similar". ${ }^{39}$ The CEAS was thought of as regulatory mechanism which should guarantee a more even distribution of asylum seekers across the Member States. The core of the system was laid down in the so-called Dublin Regulation ${ }^{40}$ which, in its revised version of 2013, contained inter alia procedures for the protection of asylum applicants, guaranteed the possibility for appeals to suspend the execution of the transfer for the period when the appeal is judged, as well as introduced an obligation to ensure legal assistance free of charge upon request. ${ }^{41}$ The main aim of the Dublin Regulation was the introduction of a distribution mechanism which was based on the idea of identifying a single EU Member State responsible for processing an asylum application (e.g. the first-countryof-entry-criterion). According to experts, it overburdened Southern European border countries because those countries were primarily responsible for processing asylum claims. ${ }^{42}$

In addition to the regulation, the CEAS implied the need to harmonise procedures for assessing asylum claims and ensuring that refugees and asylum-seekers had access to certain rights across Europe. Such harmonisation took place in the form of the asylum directives: the Asylum Procedures Directive, ${ }^{43}$ the Reception Conditions Directive, ${ }^{44}$ and the Qualification Directive. ${ }^{45}$ They introduced certain minimum standards within the EU integrated asylum and administrative space. This is typical for the European integrated administration as it is in other

${ }^{39}$ A Common European Asylum System - A Factsheet, p. 3; https://ec.europa.eu/ home-affairs/sites/default/files/e-library/docs/ceas-fact-sheets/ceas_factsheet_en.pdf (access 20.05.2021).

40 Regulation No. 604/2013 Establishing the Criteria and Mechanisms for Determining the Member States Responsible for Examining an Application for International Protection Lodged in One of the Member States by a Third-Coutry-National or a Stateless Person, L 180/31.

${ }^{41}$ A Common European Asylum System, op.cit., p. 7; Country Responsible for the Asylum Application - An Information of the European Commission, https://ec.europa. eu/home-affairs/what-we-do/policies/asylum/examination-of-applicants_en (access 20.05.2021).

${ }^{42}$ See ibidem. Cf. N. Zaun, op.cit., p. 4.

${ }^{43}$ Directive 2013/32/EU on Common Procedures for Granting and Withdrawing International Protection, 26.06.2013, L 180/60.

44 Directive 2013/33/EU Laying Down Standards for the Reception of Applicants for International Protection, 26.06.2013, L 180/96.

45 Directive 2011/95/EU on Standards for the Qualification of Third-Country Nationals or Stateless Persons as Beneficiaries of International Protection, for a Uniform Status for Refugees or for Persons Eligible for Subsidiary Protection, and for the Content of the Protection Granted, 13.12.2011, L 337/9. 
areas of its activity. In the case of migration policy, which is characterised by a high level of sensitivity, inter alia due to the problem of social acceptance of political decisions taken in this area and the direct impact of these decisions on the security of citizens, including economic security, minimum harmonisation by means of directives is a particularly difficult process. ${ }^{46}$ It was therefore feared that the phenomenon of the so-called race to the bottom will occur, i.e. the implementation of EU standards of the lowest common denominator or even lower even in those Member States that previously provided higher protection standards. Surprisingly, that was not the case. In the Member States with high levels of protection, the status quo was preserved or they even improved the guaranteed protection, whereas in the Southern European countries, e.g. in Greece or Italy, the asylum directives were not implemented completely. As a result, these countries provided less protection than required. ${ }^{47}$

The crisis has forced a redefinition of existing harmonisation efforts. In September 2020, the European Commission proposed the New Pact on Migration and Asylum. ${ }^{48}$ This is a programme of profound reform of asylum and migration policy of the European Union, which contains not only a number of concrete legislative proposals changing the legal situation in this area, but also modernises the institutional framework by introducing a new, decentralised EU Agency - the EU Asylum Agency (EUAA) which will replace the EASO and is intended by the European Commission to become a fully-fledged EU agency. Decisions in this regard were taken in June 2021. ${ }^{49}$

Among the most important elements of the New Pact, which significantly modernises CEAS mechanisms, are:

- a new asylum and migration management system which will replace the system introduced by the Dublin Regulation and should guarantee a better allocation of asylum applications between the Member States by means of a new solidarity mechanism;

- temporary and extraordinary measures to address crisis and force majeure situations in the field of migration and asylum;

- the Eurodac Regulation to improve the EU fingerprint database for asylum seekers;

46 See S. Cattacin et al., Difference Sensitivity in the Field of Migration and Health, Malmö 2007, pp. 11 ff.

47 N. Zaun, op.cit., p. 5.

48 See https://ec.europa.eu/home-affairs/news20200923/new-pact-migration-asylum-setting-out-fairer-more-european-approach_en (access 20.05.2021).

49 More: https://www.easo.europa.eu/news-events/easo-welcomes-agreement-establishing-eu-agency-asylum (access 1.07.2021). 
- a new compulsory pre-entry screening, consisting of identification, health and security checks, as well as fingerprinting and registration in the Eurodac database;

- legislative proposals reforming the three above-mentioned asylum directives;

- as well as the introduction of a permanent EU resettlement framework..$^{50}$

\section{"Agencification" in the Field of Asylum and Migration Policies}

In addition to the harmonisation component discussed above, which involves the creation of common law implementation mechanisms as indicated by the CEAS example, there is an important institutional component within the European integrated administration. In the case of asylum policy, it has been related to the functioning since 2010 of the European Asylum Support Office - EASO. The agency has undergone far-reaching modifications as the crisis has unfolded..$^{51}$ They can be pointed to as an example of the progressive institutionalisation of the European administration - as part of a broad trend of changes in the powers of EU decentralised agencies in response to the crisis. ${ }^{52}$ Another example is the European Medicines Agency and its reform during the Covid-19 pandemic crisis, ${ }^{53}$ or the European Banking Agency, entrusted with new tasks as a result of the constitutionalisation of European administration in the banking sector. ${ }^{54}$ This trend is ongoing and is reflected in secondary legislation. Modifications to the powers of individual agencies are made either by amending the founding regulations or by introducing new regulations establishing a "new" agency in an "old" area (EASO and Frontex being examples). ${ }^{55}$

${ }^{50}$ EU Asylum Reform, https://www.consilium.europa.eu/en/policies/eu-migrationpolicy/eu-asylum-reform/ (access 20.05.2021).

${ }^{51}$ The process began already in 2016. See S. Katz, A More Acceptable Solution: the Proposed European Union Agency of Asylum and Refugees, "Case Western Reserve Journal of International Law", no. 49/2017, pp. $275 \mathrm{ff}$.

52 See e.g. M. Everson, European Agencies: Barely Legal?, in: European Agencies in between Institutions and Member States, eds. M. Everson et al., Alphen aan den Rijn 2014, pp. 49 ff.;

53 See N. Nolen, P. Stockebrandt, New Competences for the European Medicines Agency, “CEP Policy Brief”, no. 12/2021, pp. 3 ff.

54 See M. Koetter et al., Completing the European Banking Union: Capital Cost Consequences for Creditproviders and Corporate Borrowers, "IWH Discussion Papers", no. 4/2021, pp. 4 ff.

${ }_{55}$ More on the often questionable legal basis for establishing and reforming the powers of EU decentralised agencies: N. Sölter, Rechtsgrundlagen europäischer Agenturen im Verhältnis vertikaler Gewaltenteilung, Berlin 2017, pp. 94 ff. 
EASO was one of many EU information agencies with limited competences. Analysts undertaking research on the effectiveness of EU administration classify such agencies as support agencies which do not necessarily contribute to real change in EU governance. ${ }^{56}$ They are primarily associated with the activities of a consultative, educational, or promotional nature without actually contributing to any changes of a normative or administrative nature in the area of their activity. Andreas Orator, who has performed an impressive review of all of the nearly forty EU agencies in terms of their scope of competence, placed EASO in 2017 in to the group of so-called plain agencies (Germ. schlichte Agenturen). These are bodies focusing primarily on tasks such as information exchange, training, and risk analysis. ${ }^{57}$

After the changes triggered by the migration crisis which resulted in the expansion of competences and the transformation of the structure of EASO in 2021, it can be counted among the group of EU decision-making agencies (Germ. entscheidungsbefugte Unionsagenturen). ${ }^{58}$ EUAA will undertake interviews with asylum seekers and submit recommendations that should be followed and formally endorsed by national administrations ${ }^{59}$ It should be seen "as a vessel to overcome the policy implementation gap (and) as a vessel to enhance inter-state solidarity". 60

The new agency will have a significant role in the monitoring and assessment of the CEAS. The monitoring mechanism will be introduced on the implementation of all aspects of the CEAS, on compliance with operational standards, and on the capacities of Member States and their financial resources, including judicial systems. It will allow the EUAA to prevent deficiencies in Member State asylum systems. ${ }^{61}$ The Agency should coordinate a common analysis on asylum issues and publish Country Guidance. The EUAA will also be active in cooperation with

${ }^{56}$ E.g. G. Pastorella, Technocratic Governments in Europe: Getting the Critique Right, "Political Studies", no. 4/2016, pp. 948 ff.

57 See A. Orator, Möglichkeiten und Grenzen der Einrichtung von Unionsagenturen, Tübingen 2017, pp. 134, 140; L. Tsourdi, Holding the European Asylum Support Office Accountable for its Role in Asylum Decision-Making: Mission Impossible, "German Law Journal", no. 21/2020, pp. $506 \mathrm{f}$.

58 A. Orator, op.cit., p. 98. Cf. Proposal for a Regulation of the European Parliament and of the Council on the European Union Agency for Asylum and Repealing Regulation (EU) No 439/2010 (First reading) - Extended Negotiation Mandate for Negotiations with the European Parliament, 2016/0131(COD), 17.06.2021.

59 See S.F. Nicolosi, D. Fernandez-Rojo, Out of Control. The Case of EASO, in: Controlling EU Agencies. The Rule of Law in a Multi-Furisdictional Legal Order, eds. M. Scholten, A. Brenninkmeijer, Cheltenham 2020, p. 177.

${ }^{60}$ L. Tsourdi, op.cit., p. 506.

${ }^{61}$ Moving On with the EU Asylum Agency, "ECRE's Policy Note”, no. 31/2021, p. 3. 
third countries and should support them in their capacity building. The Agency can establish liaison officers not only in the Member States but also in third countries. The position of a Fundamental Rights Officer is being planned, one who will ensure respect for fundamental rights in the activities of the Agency. Formal accountability will be strengthened by social accountability which should be guaranteed by the Consultative Forum of Society Organizations. ${ }^{62}$

At the time of writing, the final version of the founding regulation of the EUAA has not yet been formally approved by the Council of the EU and the European Parliament, so the text has not yet been published in the Official Journal of the EU. The agency should start its work under the new extended mandate later this year. ${ }^{63}$

\section{Conclusions}

In a crisis situation, the same question is repeatedly asked: is it necessary to take centralising measures or would it be advisable instead to decentralise? The institutionalising of the CEAS system and strengthening of the EUAA's role show that the trend towards centralising administrative tasks in the structures of the integrating Europe is still strong, even though various doubts exist if "an emergent executive order" fully corresponds with the integration idea expressed in the Treaty law.

Modifying the implementation of asylum directives within the CEAS is a deliberate step. It is supposed to be a response to the lack of consistency in terms of standards applied in the Member States. In the case of the EUAA, its operability has been strengthened. The agency, akin to its sister agencies, is to become an actual coordinator of activities in the regulated area, and not just an information platform. A separate question - unresolved in the case of most decision-making agencies - is the issue of accountability, which, according to many experts monitoring the new powers of the EASO on an ongoing basis, is not sufficient.

These considerations can be concluded with the sad reflection that the ideal of European integrated administration, which draws its models from ideas used in national normative orders, such as Germany's, is, in reality, difficult to realise at an intergovernmental level. Such international, even highly integrated administrative systems rarely meet transparency and participatory requirements. Consultation mechanisms are used mainly by specific stakeholders' groups interested in specific legislative solutions.

62 S.F. Nicolosi, D. Fernandez-Rojo, op.cit. pp. 186 ff.; https://www.easo.europa.eu/ news-events/easo-welcomes-agreement-establishing-eu-agency-asylum (access 2.07.2021).

${ }^{63}$ Ibidem. 
Crises pose a major challenge to decision-making. They usually highlight (as in the case of asylum and migration policy), various procedural and institutional weaknesses. The question remains whether the new solutions, usually involving an increased degree of legal harmonisation, will bring the expected stability in case of another crisis.

\section{Acknowledgement}

This research was supported by an NCN (Narodowe Centrum Nauki / National Center of Science, Poland) grant entitled "The Legal Challenges of Innovative Public Governance” (Project No. 2018/30/M/HS5/00296).

\section{References}

Argento D., et al., The Externalization of Local Public Delivery: Experience in Italy and Sweden, "International Journal of Public Policy", no. 1/2010.

Bezubik M., Bundestag a parlamenty krajowe, "Białostockie Studia Prawnicze", no. 4/2019.

Cassese S., Der Einfluß des gemeinschaftsrechtlichen Verwaltungsrechts auf die nationalen Verwaltungssysteme, "Der Staat", no. 33/1994.

Cattacin S., et al., Difference Sensivity in the Field of Migration and Health, Malmö University, Malmö 2007.

Chamon M., EU Agencies. Legal and Political Limits to the Transformation of the EU Administration, Oxford University Press, Oxford 2016.

Chesterham S., Globalisation and Public Law: A Global Administrative Law?, in: Sanctions, Accountability and Governance in Globalised World, eds. J. Farrall, K. Rubinstein, Cambridge University Press, Cambridge 2009.

Cuadrado-Ballesteros B., The Impact of Functional Decentralization and Externalization on Local Government Transparency, "Government Information Quarterly", no. 2/2014.

Curtin D., Egeberg M., Tradition and Innovation: Europe's Accumulated Executive Order, in: Towards a New Executive Order in Europe, eds. D. Curtin, M. Egeberg, Routledge, London-New York 2009.

Dahrendorf R., Class and Class Conflict in Industrial Society, Stanford University Press, Stanford 1959.

Estevens J., Migration Crisis in the EU: Developing a Framework for Analysis of National Security and Defence Strategies, "Comparative Migration Studies", no. 6/2018.

Everson M., European Agencies: Barely Legal?, in: European Agencies in between Institutions and Member States, eds. M. Everson et al., Wolters Kluwer, Alphen aan den Rijn 2014. 
Glencross A., E Pluribus Europa? Assessing the Viability of the European Union by Analogy with the Early American Republic, "International Social Science Review", no. 1-2/2009.

Glencross A., What Makes the EU Viable? European Integration in the Light of the Antebellum US Experience, Palgrave Macmillan, Basingstoke 2009.

Grzeszczak R., The Concept and Practice of Good Governance in the European Union, "International Journal of Social, Behavioral, Educational, Economic Law and Political Sciences", no. 2/2015.

Grzeszczak R., Towards a European Administrative Space, "University of Warsaw Journal of Comparative Law", no. 1/2014.

Hegele Y., Explaining Bureaucratic Power in Intergovernmental Relations, "Public Administration", no. 4/2019.

Heidbreder E., Structuring the European Administrative Space: Policy Instruments of Multi-level Administration, "Journal of European Public Policy", no. 5/2011.

Hofmann H.C.H., A European Regulatory Union? The Role of Agencies and Standards, in: Research Handbook on the Law of the EU's Internal Market, eds. P. Koutrakos, J. Snell, Edward Elgar, Cheltenham 2017.

Hofmann H.C.H., Mapping the European Administrative Space, "West European Politics", no. 4/2008.

Hoffmann S., Obstinate or Obsolete? The Fate of the Nation-State and the Case of Western Europe, "Deadalus", no. 3/1966.

Karpen U., Competition versus Cooperation: German Federalism in Need of Constitutional Amendments, „Amicis Curiae”, no. 70/2007.

Katz S., A More Acceptable Solution: the Proposed European Union Agency of Asylum and Refugees, "Case Western Reserve Journal of International Law", no. 49/2017.

Koetter M., et al., Completing the European Banking Union: Capital Cost Consequences for Creditproviders and Corporate Borrowers, "IWH Discussion Papers", no. 4/2021.

Kohtamäki N., Theorising the Legitimacy of EU Regulatory Agencies, Peter Lang, Berlin 2019.

Lopes D., Polyarchies, Competitive Oligarchies, or Inclusive Hegemonies? 23 Global Intergovernmental Organizations Compared, "GIGA Working Papers", no. 265/2015.

Malan J., et al., The Cost of Non-Agencies with Relevance to the Internal Market, „Policy Department D. Budgetary Affairs”, no. PE 572.702/2016.

Moisio A., et al., Public Services at the Local Level. The Finnish Way, "Government Institute for Economic Research. Policy Reports", no. $2 / 2010$. 
Nicolosi S.F., Fernandez-Rojo D., Out of Control. The Case of EASO, in: Controlling EU Agencies. The Rule of Law in a Multi-furisdictional Legal Order, eds. M. Scholten, A. Brenninkmeijer, Edward Elgar, Cheltenham 2020.

Nolen N., Stockebrandt P., New Competences for the European Medicines Agency, “CEP Policy Brief”, no. 12/2021.

Orator A., Möglichkeiten und Grenzen der Einrichtung von Unionsagenturen, Mohr Siebeck, Tübingen 2017.

Osborne S.P., Brown, K., Managing Change and Innovation in Public Service Organisations, Routledge, London 2005.

Parker D., Kirkpatrick C., Measuring Regulatory Performance, "OECD Expert Paper", no. 3/2012.

Pastorella G., Technocratic Governments in Europe: Getting the Critique Right, "Political Studies", no. 4/2016.

Peters A., Peter S., International Organizations: Between Technocracy and Democracy, in: The Oxford Handbook of the History of International Law, eds. B. Fassbender, A. Peters, Oxford University Press, Oxford 2012.

Phelan W., What is Sui Generis about the European Union? Costly International Cooperation in a Self-Contained Regime, "International Studies Review", no. 3/2012.

Risse-Kappen T., Exploring the Nature of the Beast: International Relations Theory and Comparative Policy Analysis Meet the European Union, "Journal of Common Market Studies", no. 1/1996.

Ruffert M., European Administrative Law. Annual Report: Germany, "Ius Publicum Network Review", October 2011.

Ruffert M., Walter C., Institutionalised International Law, Nomos, BadenBaden 2015.

Scharpf F., The Foint-Decision Trap: Lessons from German Federalism and European Federation, "Public Administration", no. 3/1988.

Schmidt-Aßmann E., Einheit und Kohärenz der europäischen Mehrebenenrechtsordnung, „Europäische Grundrechte. Zeitschrift”, no. 5-9/ 2016.

Schmidt-Aßmann E., Introduction: European Composite Administration and the Role of European Administrative Law, in: The European Composite Administration, eds. E. Schmidt-Aßmann, B. Schöndorf-Haubold, Intersentia, Cambridge 2011.

Shapiro M., „Deliberative”, „Independent” Technocracy v. Democratic Politics: Will the Globe Echo the EU?, "Law and Contemporary Problems", no. 3-4/2015.

Sölter N., Rechtsgrundlagen europäischer Agenturen im Verhältnis vertikaler Gewaltenteilung, Duncker \& Humblot, Berlin 2017. 
Tiefenbach T., New Public Management in Public Sector Organizations: The Dark Side of Managerialistic Enlightenment, "Public Administration", no. $4 / 2009$.

Trondal J., An Emergent European Executive Order, Oxford University Press, Oxford 2010.

Trondal J., et al., Unpacking International Organisations. The Dynamics of Compound Bureaucracies, Manchester University Press, ManchesterNew York 2010.

Tsourdi L., Holding the European Asylum Support Office Accountable for its Role in Asylum Decision-Making: Mission Impossible, "German Law Journal", no. 21/2020.

Widmaier U., Freriks R., Die Modernisierung öffentlicher Verwaltung. Zum Verhaltnis öffentlicher und privater Güterproduktion, "Diskussionspapiere aus der Fakultät für Sozialwissenschaft der Universität Bochum", no. $8 / 1996$.

Weiß W., Der Europäische Verwaltungsverbund. Grundfragen, Kennzeichen, Herausforderungen, Duncker \& Humblot, Berlin 2010.

Young O.R., Governance in World Affairs, Cornell University Press, IthacaLondon 1999.

Zaun N., EU Asylum Policies. The Power of Strong Regulating States, Palgrave Macmillan, Cham 2017. 